\title{
Synthesis of Certain 6-(Arylthio)uracils and Related Derivatives as Potential Antiviral Agents
}

\author{
Ali A. EI-Fmam," Mohamed A. M. Massoud," Eman R. EI-Bendary, and Magda A. EI-Sayed" \\ Department of Phamacentical Chemistry, College of Pharmacy, King Sand liniversity, P.O. Box 2457. Riyadh 11451, Satdi Arabia \\ Departments of Phamacentical Organic Chemistry and Medicinal Chemistry, Faculty of Pharmacy: \\ University of Mansoura, Mansoura 355/6, Egypt \\ Received April 29.2004
}

\begin{abstract}
New series of 6-(arylthio)uracils, 6-(4-substituted-I-piperazinyl)uracils, 2,4,5-trioxo-1//,3/1-benzothiopyrano[2,3d]pyrimidine and 5-aryl-2,4-dioxo-1/,3//-pyrimido[5,4-f]benzo[ $[, 4]$ thiazepines have been prepared and screened for their in vitro activity against herpes simplex-I virus (HSV-I) and human imınunodeficiency virus-1 (HIV-l). The in vitro cytotoxic activity was also evaluated. The results of biological testing revealed that compound 5b showed marginal activity against HSV-I, while compounds $\mathbf{5 b}$ and $\mathbf{5} \mathbf{f}$ exhibited marginal activity against HIV-I. The rest of the tested compounds were found devoid of antiviral activity against both HSV-I and HIV-I.
\end{abstract}

Key Words : Substituted uracils, Benzothiopyrano[2,3-d]pyrimidine, Pyrimido[5,4-/]benzo[1,4]thiazepines, Antiviral activity, Cytotoxicity

\section{Introduction}

Efforts have been directed towards the discovery of chemotherapeutic agents that have antiviral activity especially against human immunodeficiency virus HIV. A large number of pyrimidine nucleosides are clinically useful in the control of retroviral infections. ${ }^{1-4}$ In the last decade. Nonnucleoside reverse transcriptase inhibitors appeared to be very promising therapies in the treatment of retroviral diseases. Among the non-nucleoside derivatives, I-[(2hydroxyethoxy) methyl]-6-(phenylthio)thymine ( $\mathrm{HEP}^{\mathrm{P}} \mathrm{l}$ ) and its derivatives which represent a new class of potent antiHIV agents..$^{5-12}$ Potent antiviral activity was also reported among several tricyclic derivatives including dipyridodiazepinones, ${ }^{13.18}$ pyridazinobenzodiazepinones, ${ }^{19.20}$ dibenzoxazepinones and pyridobenzoxazepinones, ${ }^{21}$ and pyrimidobenzothiazepines. ${ }^{2-}$ In addition, several bis(heteroaryl)piperazine derivatives were introduced as potent antiviral drugs. ${ }^{2.32}$ In continuation to our researches in the field of nucleoside and non-nucleoside antiviral agents. ${ }^{25-28}$ we rationalized to synthesize new series of 1-substituted-6-(arylthio)uracils, 6(4-substituted-1-piperazinyl)uracils and the pyrimido tricyclic derivatives $2,4,5$-trioxo-l $\mathrm{H}, 3 \mathrm{H}$-benzothiopyrano[2,3-d]pyrimidine and 5-aryl-2,4-dioxo-pyrimido[5,4-f]benzo[1,4]thiazepines as potential antiviral agents.

\section{Results and Discussion}

Chemical Synthesis. 6-Chlorouracil 3, the key starting material necessary for this study, was synthesized from barbituric acid I wia reaction with phosphorus oxychloride and dimethylaniline to yield 2,4,6-trichloropyrimidine 2, ${ }^{29}$

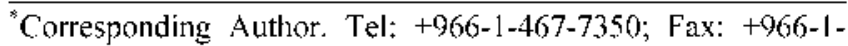
467-6220; e-mail: elemam5(athotmail.com which was subsequently hydrolysed with aqueous sodium hydroxide ${ }^{30}$ to yield 3 . Interaction of 6-chlorouracil 3 with benzyl chloride or 4-chlorobenzyl chloride in dimethylsulphoxide, in the presence of potassium carbonate yielded the corresponding $N^{1}$-substituted derivatives $4 \mathbf{a}^{31}$ and $\mathbf{4 b}$. Interaction of compounds 4a, b with thiophenol, $p$ thiocresol or thiosalicylic acid in pyridine afforded the corresponding $\mid$-(benzyl or 4-chlorobenzyl)-6-(arylthio) uracils $\mathbf{5}$ a-f (Scheme 1, Jable 1).

6-Chlorouracil 3 was similarly reacted with thiosalicylic acid to yield 6-(2-carboxyphenylthio)uracil $\mathbf{6}$, which was cyclized to 2,4,5-trioxo- $1 H, 3 H$-benzothiopyrano[2,3- $d]$ pyrimidine 7 by the action of sulphuric acid at room temperature or via heating with polyphosphoric acid (PPA) at $100-120{ }^{\circ} \mathrm{C}$. Treatment of 6 -Chlorouracil 3 with certain monosubstituted piperazines in pyridine yielded the

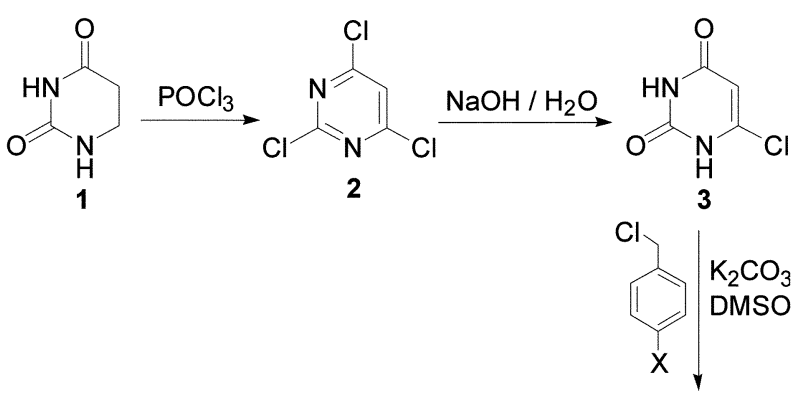<smiles>[R]c1ccc(Cn2c(Sc3ccc([R])cc3)cc(=O)[nH]c2=O)cc1</smiles>

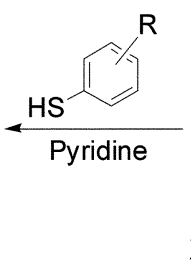<smiles>[X]c1ccc(Cn2c(Cl)cc(=O)[nH]c2=O)cc1</smiles>

Scheme 1 
Table 1. Characterization data of compounds $\mathbf{5 a - f}$

\begin{tabular}{|c|c|c|c|c|c|}
\hline $\begin{array}{l}\text { Comp. } \\
\text { No. }\end{array}$ & $x$ & $\mathrm{R}$ & $\begin{array}{l}\text { M.p. } \\
\left({ }^{\circ} \mathrm{C}\right)\end{array}$ & $\begin{array}{l}\text { Yield } \\
(\%)\end{array}$ & $\begin{array}{l}\text { Mol. Fommulat } \\
\text { (Mol. Wt.) }\end{array}$ \\
\hline $5 a$ & II & 11 & $175-7$ & 57 & $\begin{array}{c}C_{17} \mathrm{H}_{1+} \mathrm{N}_{2} \mathrm{O}_{2} \mathrm{~S} \\
(310,08)\end{array}$ \\
\hline $5 b$ & $\mathrm{Cl}$ & II & $245-7$ & 52 & $\begin{array}{c}\mathrm{C}_{17} \mathrm{I}_{13} \mathrm{ClN}_{2} \mathrm{O}_{2} \mathrm{~S} \\
(344.82)\end{array}$ \\
\hline $5 c$ & $\mathrm{II}$ & $p-\mathrm{Cl}_{3}$ & $150-2$ & 43 & $\begin{array}{c}\mathrm{C}_{18} \mathrm{H}_{1,3} \mathrm{~N}_{2} \mathrm{O}_{2} \mathrm{~S} \\
(324.40)\end{array}$ \\
\hline $5 d$ & $\mathrm{Cl}$ & $p-\mathrm{CH}_{3}$ & $205-8$ & 42 & $\begin{array}{c}\mathrm{C}_{18} \mathrm{H}_{15} \mathrm{ClN} \mathbb{N}_{2} \mathrm{O}_{2} \mathrm{~S} \\
(358.84)\end{array}$ \\
\hline $5 e$ & $\mathrm{H}$ & $o-\mathrm{COOH}$ & $280-1$ & 56 & $\begin{array}{c}\mathrm{C}_{18} \mathrm{H}_{4+} \mathrm{N}_{2} \mathrm{O}_{4} \mathrm{~S} \\
(354.38)\end{array}$ \\
\hline $5 f$ & $\mathrm{Cl}$ & $o-\mathrm{COOH}$ & $240-2$ & 52 & $\begin{array}{c}\mathrm{C}_{18} \mathrm{H}_{1 ;} \mathrm{ClN}_{2} \mathrm{O}_{4} \mathrm{~S} \\
(388.83)\end{array}$ \\
\hline
\end{tabular}

corresponding 6-(4-substituted-1-piperazinyl)uracils 8a-e (Scheme 2, Table 2).

The reaction of 6 -chlorouracil 3 with 2-aminothiophenol in ethanolic potassium hydroxide solution afforded 6-(2aminophenylthio)uracil $9,{ }^{22}$ which upon heating with substituted benzaldehydes or 2-thienaldehyde in acetic acid. underwent intramolecular Mannich type cyclization, ${ }^{32}$ to yield the corresponding 5-substituted-2,4-dioxo- $1 \mathrm{H}, 3 \mathrm{H}$ -

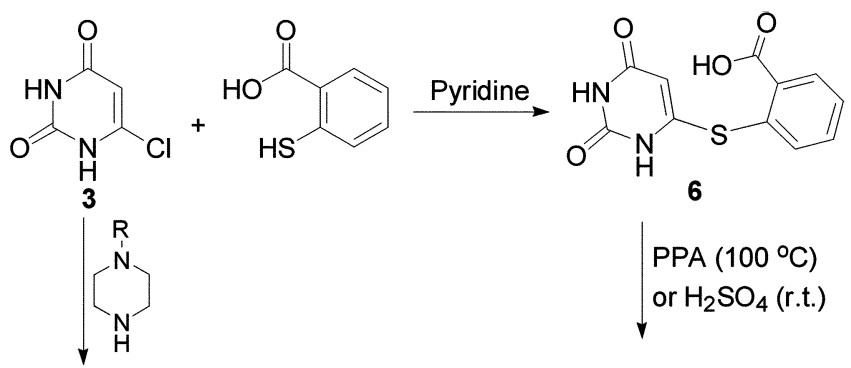<smiles>[R]N1CCN(c2cc(=O)[nH]c(=O)[nH]2)CC1</smiles>

Scheme 2

Table 2. Characterization data of compounds 8a-e

\begin{tabular}{|c|c|c|c|c|c|}
\hline $\begin{array}{l}\text { Comp. } \\
\text { No. }\end{array}$ & $\mathrm{R}$ & $\begin{array}{l}\text { Cryst. } \\
\text { Solvent }\end{array}$ & $\begin{array}{l}\text { M.p. } \\
\left({ }^{\circ} \mathrm{C}\right)\end{array}$ & $\begin{array}{l}\text { Yisld } \\
(\%)\end{array}$ & $\begin{array}{l}\text { Mol. Formulat } \\
\text { (Nol. Wt.) }\end{array}$ \\
\hline $8:$ & $\mathrm{C}^{\circ} \mathrm{H}_{5}$ & $\mathrm{AcOH}$ & $280-2$ & 43 & $\begin{array}{c}\mathrm{C}_{14} \mathrm{H}_{14_{1} \mathrm{~N}_{4} \mathrm{O}_{2}} \\
(272.30)\end{array}$ \\
\hline $8 b$ & $\mathrm{C}_{6} \mathrm{H}_{3} \mathrm{C}_{2}$ & $\mathrm{DM} / / \mathrm{H}_{2} \mathrm{O}$ & $285-8$ & 45 & $\begin{array}{c}\mathrm{C}_{1} 4 \mathrm{H}_{18} \mathrm{~N}_{4} \mathrm{O}_{2} \\
(286.33)\end{array}$ \\
\hline $8 \mathrm{c}$ & $4-\mathrm{FC}_{2} \mathrm{H}_{4}$ & $\mathrm{EtOH}$ & $285-7$ & 53 & $\begin{array}{c}\mathrm{C}_{14} \mathrm{H}_{1} \leftarrow \mathrm{F}_{4} \mathrm{O}_{2} \\
(29(1.29)\end{array}$ \\
\hline $8 d$ & 2-MeOC & $\mathrm{I}: \mathrm{tOH} / \mathrm{I}_{2} \mathrm{O}$ & $283-5$ & 50 & $\begin{array}{c}\mathrm{C}_{15} \mathrm{H}_{18} \mathrm{~N}_{4} \mathrm{O}_{3} \\
(302.23)\end{array}$ \\
\hline $8 \mathrm{e}$ & 4-MeOC: & ltoli & $220-3$ & 54 & $\begin{array}{c}\mathrm{C}_{15} \mathrm{H}_{18} \mathrm{~N}_{4} \mathrm{O}_{3} \\
(302.23)\end{array}$ \\
\hline
\end{tabular}

pyrimido[5,4-f]benzo[1,4]thiazepines 10a-j (Scheme 3 , Table 3).

In vitro Anti-Herpes Simplex-I Virus (HSV-I). The synthesized compounds were tested for their in vitro antiviral activity against Herpes simplex-1 virus (HSV-1) grown on Vero African green monkey kidney cells. The antiviral antimitotic antibiotic aphidicolin was used as a positive control, Antiviral activity is defined as confluent. relatively unaltered monolayers of stained Vero cell treated with HSV-1. The cytotoxic activity of the tested compounds was performed using Vero cell culture. ${ }^{33}$ Cytotoxicity was estimated as the concentration that caused approximately 50 $\%$ loss of the monolayer present around the placues caused by HSV-l (Table 4). An improved plaque reduction assay for antiviral activity was used to test the compounds. Plaque reduction assay typically used a monolayer of cultured host<smiles></smiles>

Scheme 3

Table 3. Characterization data of compounds I0a-j

\begin{tabular}{|c|c|c|c|c|c|}
\hline $\begin{array}{l}\text { Comp. } \\
\text { No. }\end{array}$ & $\mathrm{Ar}$ & $\begin{array}{l}\text { Cryst. } \\
\text { Solvent }\end{array}$ & $\begin{array}{l}\text { M.p. } \\
\text { ("C) }\end{array}$ & $\begin{array}{l}\text { Yicld } \\
(\%)\end{array}$ & $\begin{array}{l}\text { Mol. Formula } \\
\text { (Mol. Wt.) }\end{array}$ \\
\hline $10 a$ & $4-\mathrm{ClC}_{6} \mathrm{H}_{4}$ & $\begin{array}{c}\text { Acetons } \\
\mathrm{H}_{2} \mathrm{O}\end{array}$ & $180-3$ & 52 & $\begin{array}{c}\mathrm{C}_{17} \mathrm{H}_{12} \mathrm{CIN}_{3} \mathrm{O}_{2} \mathrm{~S} \\
(357.81)\end{array}$ \\
\hline $10 \mathrm{~b}$ & $4-\mathrm{BrC}_{6} \mathrm{H}_{4}$ & $\mathrm{EtOH} / \mathrm{H}_{2} \mathrm{O}$ & $165-7$ & 45 & $\begin{array}{c}\mathrm{C}_{17} \mathrm{H}_{12} \mathrm{BrN}_{3} \mathrm{O}_{2} \mathrm{~S} \\
(402.27)\end{array}$ \\
\hline $10 \mathrm{c}$ & $\mathrm{A}-\mathrm{FC} \cdot \mathrm{H}$ & $\mathrm{EtOH}$ & $155-8$ & 53 & $\begin{array}{c}\mathrm{C}_{17} \mathrm{H}_{12} \mathrm{FN}_{3} \mathrm{O}_{2} \mathrm{~S} \\
(341.36)\end{array}$ \\
\hline $10 \mathrm{~d}$ & 2- $\mathrm{ClC}_{4} \mathrm{H}_{4}$ & $\begin{array}{c}\text { Acetons: } \\
\mathrm{H}_{2} \mathrm{O}\end{array}$ & $152-5$ & 45 & $\begin{array}{c}\mathrm{C}_{17} \mathrm{H}_{12} \mathrm{CIN}_{3} \mathrm{O}_{2} \mathrm{~S} \\
(357.81)\end{array}$ \\
\hline $10 \mathrm{e}$ & $2.6-\mathrm{Cl}_{2} \mathrm{C}_{6} \mathrm{H}_{3}$ & $\mathrm{EtOH}$ & $159-62$ & 49 & $\begin{array}{c}\mathrm{C}_{17} \mathrm{H}_{11} \mathrm{Cl}_{2} \mathrm{~N}_{3} \mathrm{O}_{2} \mathrm{~S} \\
(392.26)\end{array}$ \\
\hline $10 \mathrm{f}$ & $\begin{array}{c}2-\mathrm{Cl}_{5}- \\
\mathrm{NO}_{2} \mathrm{C}_{\mathrm{H}} \mathrm{H}\end{array}$ & $\begin{array}{l}\text { Acetone: } \\
\text { AcOF: }\end{array}$ & $170-3$ & 62 & $\begin{array}{c}\mathrm{C}_{17} \mathrm{H}_{11} \mathrm{CIN} .1 \mathrm{O}_{1 .} \mathrm{S} \\
(402.81)\end{array}$ \\
\hline $10 \mathrm{~g}$ & $2-\mathrm{H} \mathrm{OC} \mathrm{C}_{0} \mathrm{II}$ & l:tor I & $162-5$ & 34 & $\begin{array}{c}C_{1,7} I_{1,3} \mathrm{~N}_{3} \mathrm{O}_{3} \mathrm{~S} \\
(339.07)\end{array}$ \\
\hline I0h & $4-\mathrm{CH}_{3} \mathrm{OC}_{6} \mathrm{H}_{6}$ & $\mathrm{DMF} \mathrm{II}_{2} \mathrm{O}$ & $180-3$ & 55 & $\begin{array}{c}\mathrm{C}_{18} \mathrm{I}_{15} \mathrm{~V}_{3} \mathrm{O}_{3} \mathrm{~S} \\
(353.40)\end{array}$ \\
\hline $10 \mathrm{i}$ & $\left(\mathrm{CH}_{3} \mathrm{O}_{2}\right)_{2} \mathrm{C}_{6} \mathrm{ll}_{3}$ & Itorl & $190-2$ & 38 & $\begin{array}{c}\mathrm{C}_{19} \mathrm{I} \mathrm{I}_{17} \mathrm{CIN}_{3} \mathrm{O}_{4} \mathrm{~S} \\
(383.42)\end{array}$ \\
\hline $10 \mathrm{j}$ & 2-Ihienyl & $\mathrm{HtOH} / / \mathrm{I}_{2} \mathrm{O}$ & $178-80$ & 45 & $\begin{array}{c}C_{1 \leq} \mathrm{H}_{11} \mathrm{~N}_{3} \mathrm{O}_{2} \mathrm{~S}_{2} \\
(329.40)\end{array}$ \\
\hline
\end{tabular}


Table 4. The cytotoxic and anti-HSV-I activities of compounds 5a-f, 7, 8a-e, 10a-j and the antiviral antibiotic aphidicolin

\begin{tabular}{cccc}
\hline Compound & $\begin{array}{c}\text { \% Reduction in } \\
\text { Number in } \\
\text { plaques }\end{array}$ & $\begin{array}{c}\text { Minimum } \\
\text { Antiviral Conc } \\
\text { (MAC) } \mu \mathrm{M} / \mathrm{L}\end{array}$ & $\begin{array}{c}\text { Cytotoxicity } \\
\left(\mathrm{IC}_{50}\right) \mu \mathrm{M} / \mathrm{L}^{\circ}\end{array}$ \\
\hline $\begin{array}{c}\text { Aphidicolin } \\
\mathbf{5 a}\end{array}$ & 100 & 0.02 & 0.58 \\
$\mathbf{5 b}$ & $\mathrm{B}$ & $\mathrm{C}$ & 0.23 \\
$\mathbf{5 c}$ & 30 & 0.29 & 0.09 \\
$\mathbf{5 d}$ & $\mathrm{B}$ & $\mathrm{C}$ & 0.46 \\
$\mathbf{5 e}$ & $\mathrm{B}$ & $\mathrm{C}$ & 0.61 \\
$\mathbf{5 f}$ & $\mathrm{B}$ & $\mathrm{C}$ & 0.11 \\
$\mathbf{7}$ & $\mathrm{B}$ & $\mathrm{C}$ & 1.39 \\
$\mathbf{8 a}$ & $\mathrm{B}$ & $\mathrm{C}$ & 0.13 \\
$\mathbf{8 b}$ & $\mathrm{B}$ & $\mathrm{C}$ & 0.59 \\
$\mathbf{8 c}$ & $\mathrm{B}$ & $\mathrm{C}$ & 1.05 \\
$\mathbf{8 d}$ & $\mathrm{B}$ & $\mathrm{C}$ & 0.79 \\
$\mathbf{8 e}$ & $\mathrm{B}$ & $\mathrm{C}$ & 0.17 \\
$\mathbf{1 0 a}$ & $\mathrm{B}$ & $\mathrm{C}$ & 0.56 \\
$\mathbf{1 0 b}$ & $\mathrm{B}$ & $\mathrm{C}$ & 0.07 \\
$\mathbf{1 0 c}$ & $\mathrm{B}$ & $\mathrm{C}$ & 0.08 \\
$\mathbf{1 0 d}$ & $\mathrm{B}$ & $\mathrm{C}$ & 0.06 \\
$\mathbf{1 0 e}$ & $\mathrm{B}$ & $\mathrm{C}$ & 0.11 \\
$\mathbf{1 0 f}$ & $\mathrm{B}$ & $\mathrm{C}$ & 0.64 \\
$\mathbf{1 0 g}$ & $\mathrm{B}$ & $\mathrm{C}$ & 0.45 \\
$\mathbf{1 0 h}$ & $\mathrm{B}$ & $\mathrm{C}$ & 0.38 \\
$\mathbf{1 0 i}$ & $\mathrm{B}$ & $\mathrm{C}$ & $>1.70$ \\
$\mathbf{1 0 j}$ & $\mathrm{B}$ & $\mathrm{C}$ & 0.36 \\
\hline
\end{tabular}

"IC $C_{5 n}$ : The concentration of drug that caused $50^{\circ}$, loss of the monolaver present around the plaques. B: $0^{0}$. Reduction in number of viral plaques. C: Inactive compound.

cells which were allowed to bind virus. then overlayed with a layer of medium thickened with agar or another thickener. Samples to be tested were either incorporated into the thickened laver or absorbed in a paper disc laid on the thickened layer. Abou-Karam and Shier ${ }^{3 \hat{3}}$ modified this approach to allow the production of acceptable HSV-I plaques without the use of a thickening. A serial dilutions of samples in 96-plates were used to estimate the end-point concentration for antiviral agents. ${ }^{34}$ In the same time. this assay retains the ability to estimate the cytotoxicity which is reflected as loss of the cell monolayer in which the plaques were nomally formed. Annong the 22 tested compound. compound $\mathbf{5 b}$ showed marginal activity as it reduced the number of the plaques by $30 \%$ at a ninimum antiviral concentration (MAC) of $0.29 \mu \mathrm{M} / \mathrm{L}$ with cytotoxicity $\left(\mathrm{IC}_{s i}=\right.$ $0.09 \mu \mathrm{M} / \mathrm{L}$ ). The rest of the compounds did not show any inhibitory effect against HSV-1 (Table 4). The results also revealed that the synthesized compounds showed different levels of cytotoxicity. The highest cytotoxicity was observed in compounds 5b. 10a. 10b and 10c (IC $\mathrm{IS}_{5 i}<0.1 \mu \mathrm{M} / \mathrm{L}$ ). which are all halogen containing derivatives. On the other hand, the methosy and dimethosy derivatives 10h and 10i were found to possess the lowest cytotoxic effect $\left(\mathrm{IC}_{\mathrm{si}}>1.5\right.$ $\mu \mathrm{M} / \mathrm{L}$ )

In vitro Anti-Human Immunodeficiency Virus-1 (HIV.
Table 5. The cytotoxic and anti-HПV-1 activities of compounds 5 af, 8a-e, 10a and the antiviral drug Zidovudine (AZT)

\begin{tabular}{cccc}
\hline Comp. & $\mathrm{IC}_{5_{0}}(\mu \mathrm{M} / \mathrm{L})$ & $\mathrm{EC}_{50}(\mu \mathrm{MM} / \mathrm{L})$ & $\mathrm{TI}_{5_{0}}\left(\mathrm{IC}_{5(1} / \mathrm{EC}_{50}\right)$ \\
\hline $\mathbf{5 a}$ & $>100$ & $>100$ & $>1.00$ \\
$\mathbf{5 b}$ & $>100$ & 6.5 & $>15.38$ \\
$\mathbf{5 c}$ & $>100$ & $>100$ & $>1.00$ \\
$\mathbf{5 d}$ & $>100$ & $>100$ & $>1.00$ \\
$\mathbf{5 e}$ & $>100$ & $>100$ & $>1.00$ \\
$\mathbf{5 f}$ & $>100$ & 5.25 & $>19.05$ \\
$\mathbf{8 a}$ & $>100$ & $>100$ & $>1.00$ \\
$\mathbf{8 b}$ & $>100$ & $>100$ & $>1.00$ \\
$\mathbf{8 c}$ & $>100$ & $>100$ & $>1.00$ \\
$\mathbf{8 d}$ & $>100$ & $>100$ & $>1.00$ \\
$\mathbf{8 e}$ & $>100$ & $>100$ & $>1.00$ \\
$\mathbf{1 0 a}$ & $>100$ & $>100$ & $>1.00$ \\
$\mathbf{A Z T}$ & 35.6 & 0.7 & 50.86
\end{tabular}

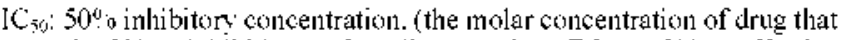
caused $50^{\circ} .0$ inhibition of cell growth). $\mathrm{EC}_{50}: 50^{\circ} .0$ effective concentration. (the molar concentration of drug that caused $50^{\circ}$. protection against $\mathrm{HIV}$ cytopathic eftect). $\mathrm{TI}_{\text {suv }}$ : Therapeutic index.

1). The procedure used to evaluate the anti-HIV-I potency is designed to detect agents acting at any stage of the virus reproductive cycle ${ }^{35}$ The assay involves the killing of $\mathrm{T} 4$ lymphocytes by HIV-1; compounds that interfere with viral activities will protect cells from cytolysis. The median effective concentration ( $\mathrm{EC}_{5 \mathrm{ii}}$ ) of the tested compounds using infected cells was compared with their cytotoxic effect (IC $\left.\mathrm{Cij}_{5 i}\right)$ in uninfected cultures. Infected and uninfected cultures were incubated without test compounds to serve as controls. Zidovudine (AZT) treated cultures were also used as a positive controls. The screening results (Table 5) revealed that the 4-cllorobenzyl derivatives $\mathbf{5 b}$ and $\mathbf{5}$ f exhibited marginal activity against HIV-1 with $\mathrm{EC}_{5 i j} 6.5$ and 5.25 $\mu \mathrm{M} / \mathrm{L}$, respectively. Although the effective concentrations of compounds $\mathbf{5 b}$ and $\mathbf{5} \mathbf{f}$ are greatly higher than that of AZT. they seemed to be less cytotoxic. The obtained results proved that $N^{\mathrm{l}}$ substitution of the uracil nucleus is essential for antiviral activity. The weak activity of compounds $5 \mathbf{b}$ and 5 and the absence of activity in the other compounds may be attributed to the lack of alkyl substitution in position 5 of the uracil nucleus as compared with the active HEPT derivatives.

\section{Experimental Section}

All melting points $\left({ }^{\circ} \mathrm{C}\right)$ were determined on fisher jolu melting point apparatus and are uncorrected. Infra red spectra were recorded in $\mathrm{KBr}$ disc using a Unicam SP 1000 infrared spectrometer and expressed in wave number $\left(\mathrm{cm}^{-1}\right)$. ${ }^{1} \mathrm{H}$ NMR spectra were obtained on a Bruker AC 250 FT NMR spectrometer at $250 \mathrm{MHz}$. the chemical shifts are expressed in $\delta$ units using tetramethylsilan (TMS) as internal reference and DMSO-d $\mathrm{d}_{6}$ or $\mathrm{CDCl}_{z}$ as solvents. Mass spectra were recorded on a Shimadzu GC-Ms-Qp $1000 \mathrm{Ex}$ instrument at $70 \mathrm{eV}$. Microanalyses $(\mathrm{C} . \mathrm{H}, \mathrm{N}, \mathrm{S}$ ) were performed in microanalytical unit. Cairo University, and 
were in agreenent with the proposed structures within \pm $0.4 \%$ of the theoretical values. The biological medium components were obtained from Signta Chent. Co., St. Louis, MO, USA.

\section{Chemical Synthesis.}

1-(4-Chlorobenzyl)-6-chlorouracil (4b). A mixture of 6chlorouracil 3 (2.93 g, $0.02 \mathrm{~mol}$ ), 4-chlorobenzyl chloride (4.83 g. $0.03 \mathrm{~mol})$ and potassium carbonate $(1.38 \mathrm{~g} .0 .01$ mol) in dimethyl sulphoxide $(20 \mathrm{~mL})$ was stirred at $60-70^{\circ} \mathrm{C}$ for 1 hour and $0.1 N$ sodium hydroxide solution $(20 \mathrm{~mL})$ was then added to the hot reaction misture with stirring. The mixture was extracted with benzene $(2 \times 10 \mathrm{~mL})$ and the aqueous phase was adjusted to $\mathrm{pH} 2-3$ with conc. $\mathrm{HCl}$. The resulting aqueous mixture was refrigerated overnight and the precipitated product was filtered. washed with water. dried and crystallized from methanol/water. Yield $3.8 \mathrm{~g}(70 \%)$. M.p. $179-180{ }^{\circ} \mathrm{C} .{ }^{1} \mathrm{H}$ NMR $\left(\mathrm{CDCl}_{\hat{j}}\right): \delta 5.1$ (s. $\left.2 \mathrm{H} . \mathrm{CH}_{2}\right), 5.9$ (s. $1 \mathrm{H}, \mathrm{C} 5-\mathrm{H}$ ). 7.45 (d, 2H, Ar-H). 7.8 (d, 2H. Ar-H), 11.5 (br s, IH. NH).

1-(Benzyl or 4-chlorobenzyl)-6-(arylthio)uracils (5a-d). A mixture of compound ta or $+b(0.002 \mathrm{~mol})$ and the appropriate thiophenol $(0.002 \mathrm{~mol})$ in $\mathrm{dry}$ pyridine $(5 \mathrm{~mL})$ was heated under reflux with stirring for 2.5 hours and allowed to stand overnight at room temperature. The mixture was then poured onto ice water $(100 \mathrm{~mL})$ and the separated solid product was filtered. washed with water. dried and crystallized from ethanol (Table 1).

5a: IR: $3310(\mathrm{NH}) .1705 .1640(\mathrm{C}=\mathrm{O}) .1150(\mathrm{C}-\mathrm{S}-\mathrm{C}) \mathrm{cm}^{-1}$. ${ }^{1} \mathrm{H} \mathrm{NMR}\left(\mathrm{CDCl}_{3}\right): \delta 4.8$ (s. IH. C5-H). 5.2 (s. $\left.2 \mathrm{H}, \mathrm{CH}_{2}\right) .7 .2-$ 7.5 (m. 10H, Ar-H). 8.8 (br s, IH. NH, D_O-exchange).

5b: IR: $3317(\mathrm{NH}), 1695,1640(\mathrm{C}=\mathrm{O}), 1135(\mathrm{C}-\mathrm{S}-\mathrm{C}) \mathrm{cm}^{-1}$. ${ }^{1} \mathrm{H} \mathrm{NMR}\left(\mathrm{CDCl}_{3}\right): \delta 4.9(\mathrm{~s} . \mathrm{H} . \mathrm{C} 5 \mathrm{H}) .5 .3\left(\mathrm{~s} .2 \mathrm{H}, \mathrm{CH}_{2}\right) .7 .1-$ 8.0 (m. $9 \mathrm{H}, \mathrm{Ar}-\mathrm{H}$ ), 8.9 (br s, $1 \mathrm{H}$. NH. $\mathrm{D}_{3} \mathrm{O}$-exchange). MS $\mathrm{m} / \mathrm{z}(\%): 346\left(0.2 \mathrm{l} . \mathrm{M}^{+}+2\right) .344(0.5 . \mathrm{M}+) .22 \mathrm{l}(0.29), 220$ $(1.47) .219(2.03), 125(64.34), 111(1.19), 109(13.84), 69$ $(56.45), 56(0.5 \mathrm{I}), 45(100)$.

5c: ${ }^{1} \mathrm{H}$ NMR $\left(\mathrm{CDCl}_{3}\right): \delta 2.35$ (s, 3H, $\left.\mathrm{CH}_{3}\right), 4.85$ (s. $\mathrm{lH}$. $\mathrm{C} 5-\mathrm{H}$ ). $5 . \mathrm{I}$ (s. $2 \mathrm{H}_{2} \mathrm{CH}_{2}$ ). 6.8-7.3 (n. 9H. Ar-H), 9.6 (br s. 1H. NH. D 2 -exchange). MS m/z (\%): $326\left(1.13, \mathrm{M}^{+}+2\right)$. $325\left(3.6, \mathrm{M}^{-}+1\right) .324\left(13.25, \mathrm{M}^{-}\right) .181(100)$.

5d: ${ }^{l} \mathrm{H}$ NMR $\left(\mathrm{CDCl}_{3}\right.$ ): $\delta 2.35$ (s. $3 \mathrm{H}, \mathrm{CH}_{3}$ ). 4.7 (s. $1 \mathrm{H}$. $\mathrm{C} 5-\mathrm{H}$ ). 5.2 (s. $2 \mathrm{H}, \mathrm{CH}_{2}$ ). 6.8-7.8 (m. 8H. Ar-H), 9.6 (br s. 1H. NH. D $2 \mathrm{O}$-exchange). MS m/z (\%): $360\left(2.23, \mathrm{M}^{+}+2\right)$. $359\left(1.64, \mathrm{M}^{+}+1\right) .358\left(5.76, \mathrm{M}^{-}\right), 125(100)$.

1-(Benzyl or 4-chlorobenzyl)-6-(2-carboxyphenylthio)uracils $(\mathbf{5 e}, \mathbf{f})$. A mixture of compound $4 \mathbf{a}$ or $\mathbf{4 b}(0.002 \mathrm{~mol})$ and thiosalicylic acid $(0.31 \mathrm{~g} .0 .002 \mathrm{~mol})$ in dry pyridine $(5$ $\mathrm{mL}$ ) was stirred and heated under reflux for 1 hour. The mixture was poured onto water $(50 \mathrm{~mL})$ and acidified with conc. $\mathrm{HCl}$. The separated reddish brown precipitate was filtered. washed with water. dried and crystallized from methanol (Table 1).

5e: 'H NMR (DMSO-d6): $\delta 4.95$ (s. 1H. C5-H). 5.4 (s. $2 \mathrm{H}$. $\mathrm{CH}_{2}$ ). 7.1-7.8 (m. 9H. Ar-H), 8.9 (br s. 1H. NH, D 20 exchange). 11.3 (s. $1 \mathrm{H}, \mathrm{COOH}, \mathrm{D}_{2} \mathrm{O}$-exchange)

5f: ${ }^{1} \mathrm{H}$ NMR (DMSO-d 6 ): $\delta 4.9$ (s. 1H. C5-H) 5.4 (s. $2 \mathrm{H}$. $\left.\mathrm{CH}_{2}\right), 7.2-7.9$ (m, 8H, Ar-H), 9.8 (br s. $1 \mathrm{H}, \mathrm{NH}, \mathrm{D}_{2} \mathrm{O}-$ exchange), $11.2\left(\mathrm{~s}, 1 \mathrm{H}, \mathrm{COOH} . \mathrm{D}_{2} \mathrm{O}\right.$-exchange $) . \mathrm{MS} \mathrm{m/z}$ (\%): $390\left(0.29 . \mathrm{M}^{-}+2\right) .389\left(0.23, \mathrm{M}^{+}+1\right), 388\left(1.03 . \mathrm{M}^{-}\right)$. $125(100)$.

6-(2-Carboxyphenylthio)uracil (6). A mixture of 6chlorouracil 3 (2.93 g. $0.02 \mathrm{~mol}$ ) and thiosalicylic acid (3.1 g. $0.02 \mathrm{~mol}$ ) in dry pyridine $(5 \mathrm{~mL}$ ) was heated under reflux for 2 hours. The mixture was poured onto cold water $(50 \mathrm{~mL})$ and the separated blue precipitate was filtered, washed with water, dried and crystallized from ethanol to yield $4.2 \mathrm{~g}(80 \%)$ of $(6)$. M.p. $279-281^{\circ} \mathrm{C}$. IR: $3455(\mathrm{COOH}), 3320(\mathrm{NH}), 1670.1640$ $(\mathrm{C}=\mathrm{O}) .1125(\mathrm{C}-\mathrm{S}-\mathrm{C}) \mathrm{cm}^{-1} .{ }^{\mathrm{j}} \mathrm{H}$ NMR (DMSO-d 6$): \delta 4.9(\mathrm{~s}$, $1 \mathrm{H}, \mathrm{C} 5-\mathrm{H}$ ). 7.6-8.1 (m, 4H, Ar-H). 9.8 (br s, 2H, 2NH, D $2 \mathrm{O}-$ exchange), $11.5\left(\mathrm{~s}, \mathrm{H}\right.$. $\mathrm{COOH}, \mathrm{D}_{2} \mathrm{O}-$ exchange $)$

2,4,5-Trioxo-1 $H, 3 H$-benzothiopyrano[2,3--l]pyıimidine (7). Method $A$ : 6-(2-Carboxyphenylthio)uracil 6 (1.1 g. $0.004 \mathrm{~mol})$ was suspended in polyphosphoric acid $(3 \mathrm{~mL})$ and heated at $100-120^{\circ} \mathrm{C}$ for 2 hours. On cooling, the syrupy mixture was treated with ice-water $(10 \mathrm{~mL})$ and the separated solid product was filtered, washed with water. dried and crystallized from ethanol to yield $0.54 \mathrm{~g}(55 \%)$ of (7). Method B: 6-(2-Carboxyphenylthio)uracil 6 (1.1 g. $0.004 \mathrm{~mol}$ ) was added to concentrated sulphuric acid $(5 \mathrm{~mL})$ and allowed to stand at room temperature for 48 hours. The mixture was poured onto crushed ice $(50 \mathrm{~mL})$ and stirred for few minutes. The resulted yellowish orange precipitate was filtered, washed with cold water. dried and crystallized from ethanol to yield $0.42 \mathrm{~g}(43 \%)$ of compound (7). M.p. 216$218^{\circ} \mathrm{C}$. IR: $3445(\mathrm{NH}), 1676.1585(\mathrm{C}=\mathrm{O}) .1125(\mathrm{C}-\mathrm{S}-\mathrm{C})$ $\mathrm{cm}^{-1} .{ }^{1} \mathrm{H}$ NMR (DMSO-d $): \delta 7.8-8.2$ (n. $4 \mathrm{H}, \mathrm{Ar}-\mathrm{H}$ ). 10.2 (br s. $2 \mathrm{H}, 2 \mathrm{NH}, \mathrm{D}_{2} \mathrm{O}$-exchange)

6-(4-Substituted-1-piperazinyl)uracils (8a-e). A mixture of 6 -chlorouracil $3(0.29 \mathrm{~g} .0 .002 \mathrm{~mol})$ and the appropriate 4 -substituted piperazine $(0.002 \mathrm{~mol})$, in dry pyridine $(5 \mathrm{~mL})$. was heated under reflux with stirring for 3 hours. On cooling. the mixture was poured onto water $(20 \mathrm{~mL})$ and the resulted reddish brown precipitate was filtered. washed with water, dried and crystallized from the appropriate solvent (Table 2).

8a: ${ }^{1} \mathrm{H}$ NMR (DMSO-d 6 ): $\delta 3.1-3.3\left(\mathrm{~m}, 8 \mathrm{H}, 4 \mathrm{CH}_{2}\right), 4.7$ (s. 1H. C5-H), 6.8-7.2 (n. 5H, Ar-H), 10.4 (br s. $2 \mathrm{H}, 2 \mathrm{NH}$ $\mathrm{D}_{2} \mathrm{O}$-exchange). $\mathrm{MS} \mathrm{m} / \mathrm{z}(\%): 273\left(3.76, \mathrm{M}^{-}+1\right) .272$ (21.19. M-). $132(100)$.

8b: ${ }^{l} \mathrm{H}$ NMR (DMSO-d 6 ): $\delta 3.2-3.35\left(\mathrm{~m}, 8 \mathrm{H},+\mathrm{CH}_{2}\right), 4.55$ (s. $\left.2 \mathrm{H}, \mathrm{CH}_{2}\right), 4.7$ (s. 1H. C5-H). 7.2-7.3 (m. 5H. Ar-H), 10.4 (br s. 2H, 2 NH, D $2 \mathrm{O}$-exchange). MS m/z (\%): 287 (1.72. $\left.\mathrm{M}^{-}+1\right) .286\left(7.66, \mathrm{M}^{+}\right) .91(100)$.

8c: ${ }^{1}$ H NMR (DMSO-d $): 83.1-3.3\left(\mathrm{~m} .8 \mathrm{H} .4 \mathrm{CH}_{2}\right) .4 .7$ (s. 1H. C5-H), 6.9-7.5 (m. 5H, Ar-H), 10.5 (br s. 2H, $2 \mathrm{NH}$ $\mathrm{D}_{2} \mathrm{O}$-exchange). MS n//z (\%): 291 (3.54. $\left.\mathrm{M}^{-}+1\right) .290$ $\left(18.89 . \mathrm{M}^{-}\right) .150(100)$.

8d: ${ }^{1} \mathrm{H}$ NMR (DMSO-d 6 ): $\delta 3.1-3.25\left(\mathrm{~m}, 8 \mathrm{H}, 4 \mathrm{CH}_{2}\right), 3.8$ (s. $\left.3 \mathrm{H}, \mathrm{OCH}_{3}\right), 4.8$ (s, $\left.1 \mathrm{H}, \mathrm{C5}-\mathrm{H}\right), 6.9-7.3(\mathrm{~m}, 4 \mathrm{H}, \mathrm{Ar}-\mathrm{H})$. 10.6 (br s. 2H. 2 NH. D 2 O-exchange).

8e: ${ }^{l} \mathrm{H}$ NMR (DMSO-d $): \delta 3.1-3.35\left(\mathrm{~m}, 8 \mathrm{H},+\mathrm{CH}_{2}\right), 3.8$ (s. $3 \mathrm{H}, \mathrm{OCH}_{3}$ ) 4.75 (s. $\left.1 \mathrm{H}, \mathrm{C} 5-\mathrm{H}\right), 6.9-7.3$ (n. $4 \mathrm{H}, \mathrm{Ar}-\mathrm{H}$ ), 10.5 (br s. 2H. 2 NH. D 2 O-exchange).

5-Aryl-2,4-dioxo-1 $H, 3 H$-pyrimido[5,4-f]benzo $[1,4]$ thi- 
azepines (100-j). A mixture of 6-(2-aminophenylthio)uracil 9 $(0.47 \mathrm{~g} .0 .002 \mathrm{~mol})$ and the appropriate aromatic aldehyde $(0.002 \mathrm{~mol})$ in glacial acetic acid $(20 \mathrm{~mL})$ was heated under reflux for 24 hours. The mixture was concentrated under reduced pressure. and water $(20 \mathrm{~mL})$ was then added to the mixture. The separated solid product was filtered. washed with water. dried and crystallized from the appropriate solvents (Table 3).

10a: ${ }^{1} \mathrm{H}$ NMR (DMSO-d $): \delta 5.7$ (d, IH. CHNH), 6.7 (d. $1 \mathrm{H}, \mathrm{CHNH}, \mathrm{D}_{2} \mathrm{O}$-exchange). $7.3-8.8 \mathrm{l}(\mathrm{m}, 8 \mathrm{H}, \mathrm{Ar}-\mathrm{H}) .10 .9$ (br s. $2 \mathrm{H}$. NH, $\mathrm{D}_{2} \mathrm{O}$-exchange). MS m/z (\%): $357\left(3.63 . \mathrm{M}^{+}\right.$ -1). $123(100)$.

10b: ${ }^{1} \mathrm{H}$ NMR (DMSO-d 6 ): $\delta 5.6(\mathrm{~d}, 1 \mathrm{H}, \mathrm{CHNH}) .6 .9(\mathrm{~d}$. $1 \mathrm{H}, \mathrm{CHNH}$. D $-\mathrm{O}$-exchange). $7.2-8.8(\mathrm{ml}, 8 \mathrm{H} . \mathrm{Ar}-\mathrm{H}$ ). 11.2 (br s. $2 \mathrm{H}$. NH. $\mathrm{D}_{3} \mathrm{O}$-exchange).

10c: ${ }^{\prime} \mathrm{H}$ NMR (DMSO-d 6 ): $\delta 5.6(\mathrm{~d}, 1 \mathrm{H}, \mathrm{CHNH}), 6.8$ (d. $1 \mathrm{H}, \mathrm{CHNH} . \mathrm{D} 2 \mathrm{O}$-exchange). 7.4-8.5 (m, 8H. Ar-H). 11.4 (br s. $2 \mathrm{H}$. $\mathrm{NH}, \mathrm{D}_{2} \mathrm{O}$-exchange). $\mathrm{MS} \mathrm{m} / \mathrm{z}(\%): 341\left(4.34, \mathrm{M}^{+}\right) .69$ (100).

10d: ${ }^{~} \mathrm{H}$ NMR (DMSO-d $): \delta 5.6$ (d. IH. CHNH). 6.85 (d. 1H. CHNH. D 2 -exchange). 7.3-8.7 (m, 8H. Ar-H). 10.9 (br s. $2 \mathrm{H}$. NH. $\mathrm{D}_{2} \mathrm{O}$-exchange).

10e: ${ }^{~} \mathrm{H}$ NMR (DMSO-d 6 ): $\delta 5.7(\mathrm{~d}, 1 \mathrm{H}, \mathrm{CHNH}), 6.9$ (d. 1H, CHNH. $\mathrm{D}_{2} \mathrm{O}$-exchange). 7.3-8.8 (m, 7H. $\mathrm{Ar}_{\mathrm{r}} \mathrm{H}$ ). 11.3 (br s. $2 \mathrm{H}$. NH. $\mathrm{D}_{2} \mathrm{O}$-exchange).

10f: ${ }^{1} \mathrm{H}$ NMR (DMSO-d $): \delta 5.7(\mathrm{~d}, 1 \mathrm{H}, \mathrm{CHNH}) .6 .95$ (d. $1 \mathrm{H}, \mathrm{CHNH} . \mathrm{D}-\mathrm{O}$-exchange). $7.5-8.8\left(\mathrm{~m}, 7 \mathrm{H} . \mathrm{Ar}_{\mathrm{r}} \mathrm{H}\right) .11 .2$ (br s. $2 \mathrm{H}$. NH. $\mathrm{D}_{2} \mathrm{O}$-exchange).

10g: ${ }^{~} \mathrm{H}$ NMR (DMSO-d $): \delta 5.75$ (d. IH. CHNH). 6.8 (d. $1 \mathrm{H}, \mathrm{CHNH}$. D 2 -exchange). 7.4-8.5 (m, 8H. Ar-H). 10.8 (br s. $2 \mathrm{H}, \mathrm{NH} . \mathrm{D}_{2} \mathrm{O}$-exchange), 11.5 (s. $\mathrm{IH}, \mathrm{OH} . \mathrm{D}_{2} \mathrm{O}$-exchange)

10h: ${ }^{1} \mathrm{H}$ NMR (DMSO-d $\left.{ }_{6}\right): \delta 3.8\left(\mathrm{~s}, 3 \mathrm{H}, \mathrm{OCH}_{3}\right), 5.65(\mathrm{~d}$. $1 \mathrm{H}, \mathrm{CHNH}$ ). 6.8 (d. $1 \mathrm{H}, \mathrm{CHNH}$. $\mathrm{D}_{2} \mathrm{O}$-exchange), 7.2-8.1 (m. $8 \mathrm{H} . \mathrm{Ar}-\mathrm{H}$ ). 10.6 (br s. $2 \mathrm{H}, \mathrm{NH}$. $\mathrm{D}_{2} \mathrm{O}$-exchange)

10i: ${ }^{1} \mathrm{H}$ NMR (DMSO-d $\mathrm{d}_{6}$ ): $\delta 3.85\left(\mathrm{~s}, 3 \mathrm{H}, \mathrm{OCH}_{\mathrm{s}}\right.$ ), 3.95 (s. $\left.3 \mathrm{H}, \mathrm{OCH}_{\hat{3}}\right), 5.6(\mathrm{~d}, 1 \mathrm{H}, \mathrm{CHNH}), 6.8$ (d, $1 \mathrm{H} . \mathrm{CHNH}$. $\mathrm{D}_{2} \mathrm{O}$-exchange). $7.2-8.3$ (m, $7 \mathrm{H}$. Ar-H). 10.6 (br s. $2 \mathrm{H}, \mathrm{NH}$. $\mathrm{D}_{2} \mathrm{O}$-exchange).

10j: ${ }^{l} \mathrm{H} \mathrm{NMR}\left(\mathrm{CDCl}_{5}\right): \delta 5.6(\mathrm{~d}, 1 \mathrm{H}, \mathrm{CHNH}) .6 .8(\mathrm{~d}, \mathrm{lH}$. $\mathrm{CHNH}, \quad \mathrm{D}_{2} \mathrm{O}$-exchange). $7.0-7.9(\mathrm{~m}, 7 \mathrm{H}$, thiophene \& Ar-H). 10.8 (br s, $2 \mathrm{H}, \mathrm{NH} . \mathrm{D}_{2} \mathrm{O}$-exchange)

In vitro Anti-Herpes Simplex-1 Virus (HSV-1). Samples were prepared by dissolving in DMSO and diluting aliquots into sterile culture medium before preparing serial dilution and placed in microtiter trays. Microtiter trays with confluent monolayer cultures of Vero cells were inverted. the medium shaken out. and replaced with serial dilutions of sterile extracts in triplicate in $100 \mu \mathrm{L}$ medium followed by tittered virus in $100 \mu \mathrm{L}$ medium containing $10 \%$ (v/v) calf serum in each well. In each tray. the last row of wells was reserved for controls that were not treated with compounds or not treated with virus. The tray were cultured and incubated at $37^{\circ} \mathrm{C}$ in $5 \% \mathrm{CO}_{2}$ atmosphere for 6 hours. The trays were inverted onto a pad of paper towels. the remaining cells rimsed carefully with medium. and fixed with $3.7 \%$ $(\mathrm{v} / \mathrm{v})$ formaldehyde in saline for 20 minutes. The fine cells were rinsed with water. and examined visually. Antiviral activity is identified as confluent. relatively unaltered monolayers of stained Vero cells treated with HSV-1. Cytotoxicity was estimated as the concentration that caused approximately $50 \%$ loss of the monolayer present around the plaques caused by HSV-I (Table 4).

In vitro Anti-Human Immunodeficiency Virus-1 (HIV1). Compounds were prepared for assay by dissolving in DMSO then diluted $1: 100$ in cell culture medium before preparing serial dilution and placed in microtiter trays. T4 lymphocytes (CEM cell line) were added and after a brief interval (1 min or more) HIV-I was added resulting in a $1: 200$ funal dilution of each of the tested compounds. Cultures were incubated at $37^{\circ} \mathrm{C}$ in $5 \% \mathrm{CO}_{2}$ atmosphere for 6 days. Tetrazolium salt XTT was added to all cells and cultures were incubated to allow formazan color development by virally infected cells. Individual wells were analyzed spectrophotometrically to quantitative formazan production and. in addition, were viewed microscopically for detection of viable cells. Results were compared with controls and zidorudine (AZT) treated wells as a positive control and a determination about activity was made as a percentage protection of T4 cells against HIV- 1 cytopathic effect (Table 5).

Acknowledgement. The authors would like to express their sincere thanks to Prof. F. Badria, Pharmacognosy department. Faculty of Pharmacy, University of Mansoura, Egypt. for carrying out the anti-HSV-l testing. and Dr. Nils Gunnar Johansson, Medivir AB. Huddinge. Sweden, for carrying out the anti-HIV-l testing.

\section{References}

1. Mitsuya. H: Weinhold. K. I.: Furman. P. A.: St. Clair. M. H.: Nusinoff-Lehrman. S.; Gallo. R. C.; Bolognesi, D. P.: Barry. D W. Broder. S. Proc. Natl Acad Sci. US.4. 1985. 82.7096.

2. Yarchoan. R.: Mitsuya, H.: Thomas, R. V: Pluda, J. M.: Hartman, N. R.: Perno. C.-F.: Marczyk. K. S.: Allain. J.-P.: John1s. D. G.: Broder. S. Science 1989. 245.412

3. Choo. H.: Chong. Y.: Choi. Y: Mathew: I.: Schinazi. R. F.: Chu. C. K. J. Med Chem. 2003 , +6. 389

4. Balzarini, J.; Pannecouque C.: De Clereq. E.: Aquaro. S.: Pemo. C.-F.: Egberink, H.: Holy. A. Antimichot Agents Chemothet: 2002. 46.2185 .

5. Myyasaka. T.: Tanaka. H.: Baba. M.: Myakawa. H.: Walker. R. T. Balzarini. T.: De Clereq. E. J. Aed Chem. 1989.32. 2507.

6. Tantillo. C.; Ding, J.: Jacobo-Molina, A.: Nanni. R. G.; Boyer, P. L: Hughes. S. H.: Pauwels. R: Andries, K.; Janssen. P. A. J.; Amold. E. J. Mol Biol 1994. 243, 369.

7. Tanaka. H.: Takashima. H.: Ubasawa. M.: Sekiya. K.: Inouye. N.: Baba. M.: Shigeta. S.: Walker. R. T.: De Clereq. E.: Myasaka. T J. Hed Chem 1995. 38. 2860.

8. Rontikis, R: Benhida. R.: Aubertin, A.-M.: Greirson, D. S. Monneret. C. J. Hed. Chem. 1996. 39. 2427.

9. Danel. K.: Larsen. E.: Pedersen, E. B.; Vestergaard, B. F; Nielsen. C. J. Med Chem 1997, t0. 1845

10. Pederset. O. S.: Pedersen. E. B. Antwiral Chem. Chemothen 1999. 10.285.

11. Mai. A.; Sbardella, G.: Artico, M.: Ragno, R.: Massa. S.; Novellino. E: Greco. G.; Lavecchia. A.: Musiu, C.: La Colla. M:; Murgioni, C.: La Colla, P.: Loddo, R. J. Hed Chent 2001. H. 2544. 
12. Nugent. R. A.: Schlachter. S. T:: Murphy. M. J.: Cleek. G. J.: Poel. T. J.: Wishka. D. R.: Yagi. Y: Keiser. B. J.: Olmsted. R. A.: Kopta. L. A: Swanev: S. M.: Poppe. S. M.: Morris, J: Tarpler: G.: Thomas. R. C. J. Hed Chent $1998,41,3793$

13. Crwin, C. L.: Klunder. J. M.: Hoemann. M.: Brickwood, J. R.: David. E.: Grob. P. M.: Schwart. R.: Pauletti. D.: Barringer. K. J.: Shih. C.-K.: Sorge. C. L.: Erickson. D. A.: Joseph. D. P.: Hattox. S. E. J. Hed Chem 1998, H1.2972.

14. Glvnn, S. L. Yazdanian, M. J. Pharm Sci, 1998, 87, 306

15. Proudfoot. I. R.: Hargrave, K. D; Kapadia, S. R.; Patel. U. R.: Grozinger, K. G.: McNeil. D. W: Cullen. E: Cardozo. M:: Tong. L.: Rose. J.: David. E.: Mauldin. S. C.: Fuchs. V. U.: Vitous, J. Hoermann. M.: Klunder. J. M.: Raghaven. P.: Skiles. J. W.: Mui. P.: Richman. D. D.: Sulivan. J. L.: Shih. C.-K.: Grob. P. M.: Adams. I. J. Afed Chent 1995. 38,4830 .

16. Kelly T. A.: Proudfoot. I. R.: MeNeil D. W.: Patel, U. R.; David, E.: Hargraye. K. D.: Grob, P. M.: Cardozo. M.: Agarwal A.: Adams. J. J. Med them. 1995 38. 4839.

17. Kelly. T. A.: McNeil. D. W.: Rose. J. M.: David. E.: Shih. C.-K.: Grob. P. M. J.Med. Chem. 1997. 40.2430.

18. Klunder J. M.: Hoemann. M: Crwin. C. L.: David. E: Brickwood. I. R.: Schwartz, R: Barringer. K. I.: Pauletti. D.: Shil. C.-K: Erickson. D. A.: Sorge. C. L.: Joseph. D. P. Hattox S. E.: Adams. J.: Grob. P. M. J. Med Chem. 1998. H1.2960.

19. Heinisch. G.: Huber. E.: Matuszczak. B.: Maurer. A.: Prillinger. U. Arch. Pharm. 1997. 330. 29.

20. Barth. B.: Dierich. G.: Heinisch. G.: Jennv: V: Matuszezak: B.: Mereiter, K: Planer, R: Schoepf I: Stoiber H: Traugott, T.: Aufschnaiter. P. V. Antmichot. Agents Chemother 1996, 7, 300.

21. Klunder. J. M.: Hargrave. K. D.: West. M.: Cullen. E.: Pal. K. Behnke. M.: Kapadia. S. R.: McNeil. D. W.: Wu. J. C.: Chow G. C.: Adams. J. J. Med Chem. 1992.35. 1887.
22. Maruenda. H.: Iohnson. F. J. Mfed Chem 1995. 38. 2145.

23. Romero. D. L.: Morge. R. A.: Biles. C.: Berrios-Pena. N.: May: P. D.; Palmer. J. R: Johnson. P. D.: Smith. H. W: Busso. M.: Tan. C.-K.: Voorman. R. L. Reusser. F.: Althaus, I. W: So. A. G.: Resnick. L.; Tarpley. W. G.; Aristoff, P. A. J. Med Chent 1994. 37.999.

24. Romero. D. L.: Olmsted. R. A.: Poel. T. J.: Morge. R. A.: Biles. C.: Keiser. B. T.: Kopta. L. A.: Friis. J. M.: Hosley. J. D.: Stefanski. K. J.: Wishka. D. G.; Evans, D. B.: Morris. J.; Stehle, R. G.; Sharma. S. K.: Yagi. Y; Voorman. R. L.: Adam, W. J.; Tarpley. W. G.: Thomas, R. C.J. Hed Chent 1996. $39,3769$.

25. El-Emam. A. A.: Pedersen. E. B.: Tacobsent. T. P.: Nielsen1. C. Bull. Soc. Chim. France 1993. 130.817.

26. Zahran. M. A.: Abdel-Megeid. A. E.-S.: Abdel-Rahnnan. A. A.: El-Emam. A. A.; Pedersen. E. B.; Nielsen. C. Heterockles 1995. H. 2507 .

27. Larsen, E.: Daniel, K.: Vaaben. G. B.; El-Emam. A. A.: Pedersen. E. B.: Nielsen. C. Acta Chem. Scand 1996. 50.417.

28. El-Emann. A. A.: Nasr. M N.: Pedersen. E. B.: Foulad. T: Nielser1. C. Phosphorts. Sulfur \& Silicone and Ret. Elements 2001. 174. 25.

29. Davoll. J.: Evans. D. D. J. Chem. Soc. 1960. 5041.

30. Cresswell, M.: Wood, H. C.S. J. Chent Soc. 1960, 4768.

31. Ishikawa. I.: Ito. I.: Melik-Ohanjanian. R. G.: Takayanıagi. H.: Mizuno. Y: Ogura. H.: Kawahara. N. Heterocucles 1990. 31. 1641 .

32. Hiramitsu, T:, Maki, Y. Swmh. Conmum. 1977. 177.

33. Abou-Karam. M.: Shier, W. T. J. Nat. Prod 1990. $53,340$.

34. Hufford, C. D.; Badria, F. A.: Abou-Karam. M.: Shier, W. T. Rogers. R. D. J Wat Prod 1991. 5t. 1543.

35. Weinslow. O. S.: Kiser. O. S.: Fine D.: Bader. T.: Shoemaker. R. H.: Bovd. M. R. J. Natl. Cancer Inst. 1989.81.577. 